\title{
Locked out of livelihoods: impact of COVID-19 on single women farmers in Maharashtra, India
}

\author{
Seema Kulkarni ${ }^{1,2}$ (D) Sneha Bhat ${ }^{1,2} \cdot$ Pallavi Harshe $^{1,2} \cdot$ Swati Satpute ${ }^{1,2}$
}

Received: 4 March 2021 / Accepted: 9 August 2021 / Published online: 12 October 2021

(c) Springer Nature Switzerland AG 2021

\begin{abstract}
This article examines the impact of COVID-19 on the livelihoods of widows and other single women farmers from the most backward districts of Maharashtra, a state in western India. COVID-19 led to food insecurity, loss of farm incomes, decline in employment opportunities and increased debt traps for single women farmers. The paper highlights how agrarian distress and pre-existing inequalities of class, caste and gender in access to food, incomes, credit, land, markets, and decision making, were exacerbated during the pandemic, further impoverishing these women farmers. To trace these effects, the paper draws on two types of evidence gathered in Maharashtra by MAKAAM, an informal all-India women farmer's forum: observations during multiple rounds of interactions with over a hundred women farmers during the COVID-support work of providing ration and seeds undertaken by MAKAAM during India's national lockdown in 2020, and a subsequent large-scale survey covering about a thousand women. The paper also focuses on the inadequacy of state response, both in terms of providing relief and in its ability to partner with women's collectives and grassroots organisations for better outcomes. The article makes a case for strengthening social security measures for women farmers and enhancing their access to productive resources, agricultural programmes and decision-making spaces in relevant institutions.
\end{abstract}

Keywords COVID-19 · Single women farmers · Widows · Livelihoods · Social security $\cdot$ Agrarian distress

JEL Classification $\mathrm{J} 16 \cdot \mathrm{O} 53 \cdot \mathrm{Q} 12$

Seema Kulkarni

seemakulkarni2@gmail.com

Extended author information available on the last page of the article 


\section{Introduction}

In response to the COVID-19 pandemic, the Indian government imposed a strict and sudden country-wide lockdown on 25 March 2020. This led to widespread hardships for women workers who lost their jobs and livelihoods. This has been well documented by a range of studies. Agarwal (2021a, b), for example, provides a detailed review and analysis of both the direct and indirect impact on women of livelihood losses, not just of women themselves but also of their spouses. Several studies have also examined the effect of job losses by migrant workers stranded in cities far from home without housing or food (CLRA, 2020; CPI-M-CITU, 2020; Mudur, 2020; SWAN, 2020). A gender-differentiated, disproportionate impact was seen on essential workers and frontline workers like the Accredited Social Health Activists (ASHAs) providing care services (Dasgupta \& Mitra, 2020), as well as self-employed women in various trades (SEWA-Bharat, 2020). Some studies have also highlighted the rise in food insecurity and indebtedness among the poor including women (CSE, 2020; CSO, 2020). And there have been reports of increased distress among small borrowers, most of whom are women (Bera, 2020). Moreover, national-level analysis has shown that while both men and women lost their jobs under the lockdown, subsequent recovery was much lower for women than men (Deshpande, 2020). Caste and gender differences played out significantly in terms of access to government relief measures as well as loss of employment (Raina \& Ananya, 2020).

In this literature, however, very few studies have focused on rural households and almost none have focused specifically on women farmers, especially those who had been widowed or deserted prior to the pandemic (Kulkarni, 2020). These women faced particular difficulties in harvesting, transporting and selling their produce (Chishti, 2020). This article seeks to bring to light the particular challenges faced by "single" women farmers in rural Maharashtra, a state in Western India. It also highlights the key policy gaps and failures which have left women farmers, who had already been neglected, much worse off during the pandemic. We will use the term "single women" for women who are widowed, deserted or unmarried. In our study, $91 \%$ of the single women are widows. They come from poor households and lack both support from their marital families after widowhood and access to the government's relief measures.

The study is located in seventeen districts of the state of Maharashtra. A majority of these districts are drought prone and have had large numbers of farmers committing suicide. Indeed, Maharashtra is known to have the largest number of farmer suicides in India. Fourteen of the 17 study districts have been declared as suicide afflicted. Between 1995 and 2018, more than 70,000 farmers killed themselves in Maharashtra, accounting for $20 \%$ of all farmer suicides in the country (National Crime Records Bureau, 2018). Men constituted $90 \%$ of the suicides, leaving behind "farm-suicide widows" urgently needing social and economic support (MAKAAM, 
2018). ${ }^{1}$ They added to the widows whose husbands had passed away from other causes, as well as women who had been deserted. This paper is based on a sample of 946 such single women surveyed during the month of May 2020. In-depth qualitative interviews were also conducted with about 25 women. The survey was undertaken under the auspices of the Mahila Kisan Adhikar Manch (MAKAAM), an all-India informal forum for women farmers' rights constituted of collectives, civil society organisations, researchers and activists from 24 Indian states, working to secure recognition and rights of women farmers. The study thus provides us with a unique picture of women who are normally invisible both to researchers and policymakers (MAKAAM 2020).

The paper is divided into 7 sections. Section 2 below gives a background to the study and outlines how the data were collected; Sect. 3 gives the characteristics of the single women studied. Section 4 discusses the kinds of problems the women faced, and Sect. 5 discusses the failure of state support. Section 6 discusses the overall findings and Sect. 7 provides concluding reflections and recommendations.

\section{Objectives and data}

The main objective of the study was to understand the impact of the pandemic, including the lockdown, on the livelihoods of women farmers and their ability to access government relief measures.

The study grew organically from the relief work initiated by MAKAAM in the first phase of the lockdown, when the government's Public Distribution System (PDS), which was meant to provide food security to the poor, had yet to streamline its operations and the growing hunger had to be addressed urgently. ${ }^{2}$ We had numerous telephonic conversations with women, starting in the last week of March. These women were selected on the basis of suggestions made by local partner nongovernmental organisations, and included women from diverse socio-economic backgrounds. The women shared with us the difficulties they were facing in earning a livelihood and their inability to access the government's relief measures. These initial conversations proved to be a major challenge as women were not familiar with telephonic conversations. Several of them did not even have their own mobile phones and depended on a male mediator. By the end of April 2020, however, we were able to instil women with the confidence to overcome the digital barrier and converse with us on platforms such as Zoom. Over a period of two months of April to May 2020, the women were able to speak with us for over an hour and share their

\footnotetext{
1 See also, https://www.soppecom.org/aboutus.htm.

2 To provide food security to the poor, the Indian government distributes food and essential non-food items at subsidised rates under the PDS, through a network of fair price shops (also known as ration shops) spread across the country. The government-run Food Corporation of India, procures the food items for the PDS.
} 
problems. Once these methodological challenges were overcome, we had a unique opportunity to co-produce knowledge and design our responses collectively.

Our initial conversations with about 50 women from across the state highlighted the need for a large-scale study. The participatory nature of the study also helped us plan ways of reversing some of the negative outcomes of the lockdown. The Society for Promoting Participative Eco-System Management (SOPPECOM) ${ }^{3}$ which anchors the State level network of MAKAAM helped in the design and analyses of the data gathered through the survey. The quantitative survey of 946 women in Maharashtra was based on a purposive sample of single women cultivators and wage labourers who are the core constituency of MAKAAM Maharashtra. Investigators associated with the 25 partner organisations of MAKAAM collected the data between 17 and 25 May 2020.

Data collection was undertaken through the COLLECT App. Investigators from MAKAAM's partner organisations were trained through an online training programme using the Zoom platform. Field-level data collection was possible in some of the districts which were categorised as the "green zones" of the state: these were zones declared by the State in May 2020 as areas where no confirmed cases of coronavirus had been found in the previous 21 days. $^{4}$ In other cases, data had to be collected telephonically. Although the findings discussed in the paper are based primarily on the larger quantitative study, they are not limited to that. We have also factored in insights gained from the discussions MAKAAM volunteers had with the women during the relief work from early April to June 2020.

\section{Background}

\subsection{Characteristics of the women}

All the women who participated in the study were single women, $91 \%$ being widows. About $28 \%$ of the widows belonged to households affected by farm suicides and $68 \%$ were in the age group 31-50 years (Table 1). About $45 \%$ were illiterate and $43 \%$ belonged to families where the woman was the only adult and therefore also the sole earning member. Caste-wise, $25 \%$ were upper caste, $21 \%$ belonged to OBCs, $13 \%$ were scheduled caste, $33 \%$ belonged to tribal communities, and the rest belonged to special backward castes and the Muslim community.

The majority of women in the study had to work in multiple jobs to make ends meet since no single occupation was adequate for subsistence. Diversifying portfolios reduced their risk of being completely without earnings, but it also increased their uncertainties. Of the total sample of 946 women, $36 \%$ were solely cultivators, $39 \%$ did both cultivation and wage labour, while $24 \%$ were dependent entirely on

\footnotetext{
3 For details, see their website, www.soppecom.org.

4 In May 2020, the state was divided into red, orange and green zones depending on the extent of known infections. Mobility was possible in the green zones while the red zones that had several active cases and a high doubling rate where under a hard lockdown.
} 
Table 1 Characteristics of the single women

\begin{tabular}{lll}
\hline Characteristics & Number of cases & $\%$ \\
\hline CASTE & & \\
$\quad$ Upper caste & 243 & 25.7 \\
Other backward caste & 202 & 21.4 \\
Scheduled caste & 126 & 13.3 \\
Scheduled tribe & 204 & 21.6 \\
Nomadic tribe & 120 & 12.7 \\
Denotified tribe & 34 & 3.6 \\
Special backward class & 10 & 1.1 \\
Muslim & 7 & 0.7 \\
Total & 946 & 100.0 \\
EDUCATION & & \\
Illiterate & 427 & 45.1 \\
1st to 4 th class & 159 & 16.8 \\
5th to 7th class & 154 & 16.3 \\
8th to 10th class & 155 & 16.4 \\
11th to 12th class & 39 & 4.1 \\
Graduation & 12 & 1.3 \\
Total & 946 & 100.0 \\
AGE & & \\
20-40 years & 409 & 43.2 \\
$>$ 40-50 years & 326 & 34.5 \\
$>$ 50 years & 211 & 22.3 \\
Total & 946 & 100.0 \\
MARITAL STATUS & & 28.0 \\
Widows due to suicide by farmer husbands & 265 & 8.9 \\
Other widows & 597 & 100.0 \\
Other single women & 84 & \\
Total & 946 & \\
\hline & & \\
& &
\end{tabular}

wage labour in agriculture and construction (Table 2). Both these categories of work were adversely impacted by the pandemic-induced lockdown.

A considerable proportion of women - 43\% - had land in their own names; $28 \%$ were landless while 29\% (278 women) cultivated land that belonged to other members of the family. Some $85 \%$ of the last category cultivated land belonging to their marital family. Some of them lived with their parental families and travelled to their marital villages to cultivate the land. On an average, the distance between the marital and parental village was about $8-10 \mathrm{kms}$. Among the landless a considerable number belonged to specially disadvantaged social categories of special backward castes, scheduled castes and scheduled tribes. Those who did own land and cultivated it, were small and marginal farmers cultivating less than 2 ha. We did not investigate whether the women owning land had received it from their parents or from their marital families. However, 
Table 2 Single women's occupations and land owned

\begin{tabular}{llc}
\hline Occupation, land owned, land irrigated & Number & $\%$ \\
\hline WOMEN'S OCCUPATION & & 36.4 \\
$\quad$ Cultivators only & 344 & 38.8 \\
$\quad$ Cultivators and wage labourers & 367 & 23.8 \\
$\quad$ Wage labourers only & 225 & 1.1 \\
$\quad$ Other & 10 & 100.0 \\
Total & 946 & 27.7 \\
OWENERSHIP OF LAND & & 42.9 \\
$\quad$ Landless women & 262 & 29.4 \\
Women owning their own land (with titles) & 406 & 100.0 \\
Women cultivating land belonging to their marital or parental & 278 & 100.0 \\
$\quad$ families & & 18.7 \\
Total & 946 & 40.6 \\
WOMEN WITH IRRIGATED LAND & & 9.1 \\
Those with own land irrigated & 128 & 31.6 \\
Those with own land unirrigated & 278 & 62 \\
Those cultivating irrigated family land & 216 & 684 \\
Those cultivating unirrigated family land & & 10 \\
Total & & \\
\hline
\end{tabular}

our work on women and land rights shows that women's landownership is primarily among widows and the land they own belongs mainly to marital households (see also Agarwal et al., 2021, for such findings across states).

Water is the most critical input for agricultural production. Only $27 \%$ women had access to irrigation, a majority of them being upper-caste women. Although we did not probe the issue of irrigation in detail, most women in our in-depth interviews said that they could only irrigate their land in one season of the year. Hence the majority still had to depend on wage work for most part. Women without land titles also face barriers in accessing bank credit and agriculture linked schemes and subsidies. Inadequate social security measures in the form of widow pensions, housing, education for children or subsidized health care facilities combined with the lack of rising costs of privatized health care and education further add to these women's economic burdens (MAKAAM, 2018).

Moreover, single women, especially those from farmer suicide households were left to fend for themselves, their children, and the elderly. They faced a special risk of being sexually harassed and exploited by private money lenders, seed dealers (in return for loans or inputs), and landlords if they took land on lease, apart from being harassed by male relatives. Additionally, they had to cope with the pandemic.

\subsection{The culitvation process}

Over the last few decades, there have been significant shifts in the cropping patterns in Maharashtra. For the state as a whole, area under food grains has declined from 
nearly $70 \%$ in $1960-61$ to $49 \%$ in $2015-16$. In particular, there has been a drastic reduction in area under cultivation of jowar and bajra (millets) which are the main food crops of the state. These have been replaced by crops like cotton, soyabean and sugarcane which are the major non-food grain crops in Maharashtra. Cotton and soyabean account for $18 \%$ and $16 \%$ respectively of the gross cropped area of the state (GoM, 2019-20).

In our study districts, cotton and soyabean are the main cash crops. Soyabean was cultivated by $41 \%$ and cotton by $35 \%$ of the women. In addition, there was intercropping with pigeon pea, green gram and other pulses. The cultivation of soyabean and cotton depends on excessive use of chemical fertilisers and pesticides, thereby increasing the cost of cultivation. Moreover, the prices of these crops depend on global markets, which makes returns uncertain. Very few women cultivate food crops like paddy, jowar or bajra, partly because the marketing infrastructure for these crops is less developed than it is for soyabean or cotton, and partly because food crops are increasingly vulnerable to animal attacks. Cropping pattern shifts over the years are a result of a policy emphasis on cash crops, with a focus on chemical-based agriculture.

In Maharashtra there are about 300 regulated market yards or mandis, and 600 sub-market yards. The state also has regulated private markets that allow direct purchase from the farmers outside the mandis. The village traders act as intermediaries both for sales in the mandis and sales to private buyers outside the mandis. The latter include the processors for crops like soyabean and pigeon pea. Cotton too is sold to village-level traders who, in turn, aggregate the purchases and sell it to the procurement agencies designated by the Cotton Corporation of India (CCI). ${ }^{5}$ Although farmers can get an assured minimum support price (MSP) ${ }^{6}$ through the government procurement system, women, tenant farmers and other small and marginal farmers find the process cumbersome due to the documentation needed and a longer wait and delayed payments.

Given women's small land holdings, the average production from an acre of rainfed land is between 3 to 4 Quintals (Q) of cotton or soyabean. Yields are low on women cultivated farms since they have little access to credit or other agricultural inputs. Small farmers, in general, but women farmers in particular are also often forced to make distress sales since they need immediate cash to repay old loans and to invest for cultivation in the next season. Moreover, they usually lack adequate storage space to hold on to their produce for a better price. Distress sales also happen because of the low volumes of produce of poorer quality. Their small outputs make it uneconomical for them to transport their produce to mandis, apart from the difficulties women face in negotiating in male dominated mandis. While selling produce to village-level traders provides them with credit, seed and other agricultural inputs, it also means that they got low prices for their produce even in pre-COVID times. This was even more the case under COVID.

\footnotetext{
5 The Cotton Corporation of India is a public sector undertaking which markets cotton in India.

6 The most recent calculation for the MSP is 50\% above the sum of paid out costs (that includes hired labour, agricultural inputs, etc.) and family labour.
} 


\section{Covid impact}

\subsection{Harvesting, sales and losses}

One of the immediate problems women farmers faced under COVID lockdown was in harvesting and selling their produce. Of the 711 women cultivators (including those who are solely cultivators as well as those cultivating along with doing wage labour) $30 \%$ said they had unharvested produce when the lockdown was announced in March 2020. Under the lockdown they could not find labour for harvesting. Labour shortage also led to high wage rates. Wages had to be paid in cash which most women lacked. Mechanical harvesters and other equipment were not available on hire due to restricted mobility during the lockdown.

Moreover, for the women who commuted from their natal villages to their marital villages for cultivating their land, the lockdown was a huge impediment. Fear of the pandemic forced some of them to remain at home and they could not go out and harvest their crop despite the fact that agriculture was exempted from the lockdown. Those who could not themselves travel to their villages had little or no support from their in-laws. They thus depended for harvesting mainly on local traders from whom they borrowed seed and other agricultural inputs. This arrangement did not work either under the pandemic.

Similarly, marketing of the harvested produce was a challenge. Only173 women cultivators said they were able to sell their produce during the lockdown. The others either sold it before the lockdown or chose to wait until the lockdown was lifted. Soyabean and cotton were the main crops that the women were trying to sell during the lockdown. Cotton and pigeon pea had been harvested prior to the lockdown and were waiting to be sold as was soyabean which was harvested in September/October 2019 but which some had held back to get a higher price. However, most women, as noted, cannot hold onto their produce for very long since they need the cash to repay loans or invest in agriculture. During the lockdown, the requirement for immediate cash increased manifold, thus compelling them to sell their produce at whatever price was possible. Table 3 compares the prices at which women were able to sell their produce during the lockdown compared to the prices received for the same crops the previous year. Almost every crop shows a price decline. They also faced problems in selling their crops due to lack of public transport, increased transport costs and damaged produce.

To illustrate the kinds of problems faced by women who commuted to their marital villages to cultivate their lands, consider the case of Neelima Tai. She is a 33 year old widow from Yavatmal district, who has one minor child. Her husband committed suicide a few years ago, after which she had to leave her marital home due to harassment from in-laws. She lived in her parents' village and commuted daily to cultivate her husband's share of the land which was still in her father in law's name. This daily commute of 1 hour leaves her tired but it is the major source of her livelihood. She had harvested her pigeon-pea and cotton when the lockdown was announced. But she had managed to sell only a small amount of the cotton prior to the lockdown at a price of Rs 5200/Q. After the lockdown she had to sell the cotton with the help of her in-laws 
Table 3 Decline in prices received during the 2020 lockdown by crop

\begin{tabular}{llll}
\hline Crops & \multicolumn{2}{l}{ Price received (Rs. per quintal) } \\
\cline { 2 - 4 } & $\begin{array}{l}\text { During the 2020 } \\
\text { lockdown }\end{array}$ & In 2019 & $\begin{array}{l}\text { Difference in prices } \\
\text { 2020 vs. 2019 }\end{array}$ \\
\hline Bajra & 1500 & 1500 & 0 \\
Black gram & 2300 & 3400 & -1100 \\
Cotton & 3901 & 5528 & -1627 \\
Gram & 4620 & 4720 & -100 \\
Jowar & 1891 & 2264 & -373 \\
Maize & 1500 & 2050 & -550 \\
Sesame & 5300 & 6300 & -1000 \\
Soybean & 2991 & 3486 & -495 \\
Pigeon pea & 4316 & 4778 & -462 \\
Wheat & 1579 & 1625 & -46 \\
Yellow lentils & 2550 & 2550 & 0 \\
\hline
\end{tabular}

Source: Data gathered from women during the survey

and neighbours at a price of Rs 4700/Q which is Rs 500/Q less than the price she got before the lockdown. She was still holding on to her pigeon-pea crop at the time of this survey as the prices offered by the local traders were very low.

Of the 173 women who sold their produce in this period, $74 \%$ sold it to villagelevel traders and 26\% through mandis. Our in-depth interviews showed that those who sold to the mandis often had to go through private traders since they cannot easily access the mandis even in normal times due to long distances involved. Some illustrative examples of women's experiences are given below:

Vanita tai from Osmanabad said "markets are to be accessed at the convenience of men from the village, whenever their vehicle heads out, we have to load our produce which has often meant delays and loss of the value of the produce". Dwarkatai a dalit cultivator says "being a dalit and a single woman, I am not able to hire labour for harvest in a timely manner. Moreover, availability of a vehicle to transport our produce to the market is also only after the upper-caste male farmers have loaded their produce".

Shaila from Osmanabad explained: "I don't go to the mandis because it is a very male dominated space, there are many vehicles, big vehicles and many men. I have never seen a woman there".

Vanitatai further told us that she is forced to sell to the local trader who provides seed and other agricultural inputs to her. "I take my produce to the processor where the local trader who provided me the credit comes in, weighs the produce, gives me a price after deducting the principal amount and the interest on it. Selling our produce at the government procurement centres is not easy. Firstly, revenue records need to be in our name, online registration is needed and we have to make sure that our produce is taken to the centre on the day we are asked to. We also need to bribe so that they give us a good rate". This year however Vanita tai had to sell it to the 
local trader as she could not travel to the neighbouring town where the processor mills were located.

Apart from the main crops, women also sell commodities like eggs, milk, vegetables in the neighbouring larger villages. These are perishable, which they could not sell under the lockdown as restaurants, sweet meat shops in larger villages and towns were shut. The local village market was saturated as there were more producers than consumers for the perishable produce.

\subsection{Loans and liabilities}

With reduced or no earnings, the women farmers reported that they could not repay their previous loans. Archanatai from Latur said: "I have spent sleepless nights over produce that was yet to be sold. I decided to wait for a month and sell it even if the price was low as the burden of loans is too high. I have borrowed from the Agricultural credit co-operatives, from microfinance institutions (MFIs) and also from the Self-help groups (SHGs)."

Parvatabai, a tenant farmer from Nagpur district borrows from multiple sources every season to service the older loans and invest in her farm. In April of 2020 she was worried about how to hold on to her leased in land, pay for the irrigation water, and repay the old loans.

The problem of repaying old loans and accessing new loans becomes critical, given that most women have lost their earnings and many have not been able to meet their cost of production. Pre-pandemic, in 2019, 352 women (50\% of the cultivators) had taken loans for farming from banks and several informal sources. Informal loans were at very high interest rates of $24-36 \%$ or more. Among those who had borrowed, only $28 \%$ were able to repay. The defaulters had few prospects of borrowing from the same or similar sources. The challenge in the Kharif season (July to October of 2020) was thus daunting.

Lakshmibai said:

"The micro finance institutions (which are mainly the non-banking financial companies lending money to vulnerable women) did not send their recovery agents as they could not come into the villages, but we know that the clock is ticking and that the loans would not be waived off. I had already pawned my gold last year and sold a cow too. How will we now repay our loans?"

Many women also reported that the agricultural credit co-operative societies have sent them warnings to pay up the loans at an increased monthly interest rates after March 2020 from 3 to $5 \%$.

By the end of May 2020, their scarce supplies of food and cash had been depleted and women were worried that they would be unable to rebuild their livelihoods in the post lockdown agricultural season. In our early April 2020 conversations, women were thinking of shifting from cotton to food grains so that they would at least have food during the crisis. Besides, cotton has a high cost of cultivation. Some of them said they would lease out their lands or leave them fallow since they lacked the cash to invest in agriculture and had exhausted all their borrowing options. 
By the time this survey was conducted, 94\% women across 17 districts said that they would be cultivating the predominant crops grown in their areas as there was no price assurance for other crops. However, several of them said they would reduce the area under cotton and grow soyabean and pigeon pea instead. The cost of seed, fertilisers and pesticides had increased and government subsidies on agricultural inputs had declined. A delayed monsoon and failure of soyabean seed, followed by untimely rains, continued to disrupt the farm livelihoods of women in these districts one year on.

\section{Failure of state support}

Given their inability to earn enough from cultivation and growing indebtedness, most women had to turn to other means of earning a living. The government of India has programmes for vulnerable populations that guarantee certain social and economic security entitlements. For example, food security is ensured to a large section of economically vulnerable groups under the National Food Security Act (NFSA 2013). There is also 100 days of employment guarantee per household under the Mahatma Gandhi National Rural Employment Guarantee Act (MNREGA 2005). This scheme is sponsored by the central government. In addition, the state of Maharashtra has a special Employment Guarantee Scheme (EGS) dating from the 1970s (Shah \& Mehta, 2010). This currently guarantees work for 265 days per rural household. Besides these entitlements, there are several social and economic security schemes such as the pension schemes applicable for widows, the old and disabled people or direct income transfer schemes for farmers who can fulfil certain eligibility criteria.

Here we examine the effectiveness of two sources of potential support for the women: the government's employment guarantee scheme and the Covid-19 relief measures announced by the government which are relevant to women.

\subsection{The Mahatma Gandhi National Rural Employment Guarantee Act (MNREGA)}

Wage labour, as noted, is a critical component of rural women's livelihoods. While they cultivate for part of the year, it is wage labour that helps them repay their loans and meet day to day expenses. For most women cultivating unirrigated dry lands, wage labour is the only source of income during the lean season.

The lockdown brought a sudden closure of work, transport services came to a halt leaving agricultural wage labourers without work and cultivators without labour. Among the 592 women who are engaged in wage labour, $45 \%$ did not get a single day of work from the day the lockdown was announced till the end of May (Table 4). During April to May, the total earnings of the majority of those who did find some work, were less than Rs 3000. It is during such crisis that public systems become very critical. For women dependent largely on agricultural wage labour this was a difficult period due to lack of work since farmers did not have the cash to pay 
Table 4 Availability of wage work

\begin{tabular}{llr}
\hline Characteristics of women who work as labourers & No of cases & $\%$ \\
\hline Work available during lockdown & & 44.6 \\
No work & 264 & 43.6 \\
$1-15$ days & 258 & 11.8 \\
$>15$ days & 70 & 100.0 \\
Total & 592 & \\
\hline
\end{tabular}

labourers; also, they had family labour available due to the lockdown and returning migrants.

In this context, MNREGA and the State EGS could have provided critical support. However, despite the presence of both the MNREGA and the State EGS, rural works under these schemes had not begun till the end of May 2020. Of the total 946 women in our sample only $37 \%$ women had job cards (the document necessary for taking advantage of MNREGA); $11 \%$ demanded work, and only 32 (3\%) actually received any work during the lockdown. An overwhelming majority (76\%) said that they did not know how to demand work under the MNREGA. Others faced another bottleneck: many jobs under this programme exclude single women as they require a couple to work as a unit. Those who got work faced delayed and inadequate payments.

\subsection{Other COVID-19 relief measures}

The state response were both inadequate and tardy. Soon after the national lockdown was initiated, the Indian prime minister announced the first large scale relief programme (Pradhan Mantri Garib Kalyan Yojna or PMGKY) for Rs 1.70 lakh crore. Under the PMGKY, cash transfers were promised to various categories of the poor (GOI, 2020). Women with the needed accounts the Jandhan accounts were to receive Rs 500 per month for three months. In addition, an ex-gratia payment of Rs 1000 was to be made into the accounts of the existing pension beneficiaries: widows, old age people, and those with disabilities. The pension scheme is an old one and the government did not expand it to include new beneficiaries as part of the Covid-19 relief measures.

Another government scheme was to give cooking gas (LPG) cylinders free of cost for three months to poor families under the Ujjwala gas scheme, by advancing funds to women's bank accounts. However many families did not receive the advance funds. Also the scheme was limited to existing beneficiaries and did not add any new ones, despite the hardships faced by a large number of women. Moreover, the scheme was changed in June 2020: the women were now required to first purchase the third cylinder and then seek reimbursement by providing a receipt. The women did not have funds for such a purchase.

Similarly, the PM Kisaan Sanman Nidhi is an existing scheme that makes a cash transfer of Rs 6000/year to farmers with a land holding of less than 2 ha, in 
Table 5 Beneficiaries of government relief measures under the PMGKY scheme

\begin{tabular}{lll}
\hline Relief measures under COVID-19 & No of women & $\%$ \\
\hline JANDHAN ACCOUNT & & \\
$\quad$ Not listed as beneficiary & 524 & 55.4 \\
$\quad$ Listed and benefit received & 328 & 34.7 \\
$\quad$ Listed but no benefit received & 94 & 9.9 \\
Total & 946 & 100.0 \\
WIDOW PENSIONS & & \\
$\quad$ Not listed as beneficiary & 568 & 60.0 \\
$\quad$ Listed and benefit received & 328 & 34.7 \\
$\quad$ Listed but no benefit received & 50 & 5.3 \\
Total & 946 & 100.0 \\
COOKING GAS SCHEME (Ujwala) & & \\
$\quad$ Not listed as beneficiary & 633 & 66.9 \\
$\quad$ Listed and benefit received & 148 & 15.6 \\
Listed but no benefit received & 165 & 17.4 \\
Total & 946 & 100.0 \\
SCHEME FOR FARMERS (PM Kisan Sanman Nidhi) & & \\
$\quad$ Not listed as beneficiary & 389 & 56.9 \\
$\quad$ Listed and benefit received & 265 & 38.7 \\
Listed but no benefit received & 30 & 4.4 \\
Total & $684^{a}$ & 100 \\
\hline
\end{tabular}

Note: These 684 women are from land owning households

three instalments of Rs. 2000/each. During the lockdown, no new beneficiaries were added and neither was any additional money given to the existing beneficiaries. As part of the COVID-19 relief measures, the beneficiaries were entitled to an advance instalment of Rs 2000/- Very few women have land in their name and therefore do not get listed as beneficiaries. Besides this, free distribution of rice and pulses was to be provided through the Public Distribution System (PDS).

Our study shows that a majority of the women are in fact not listed as beneficiaries of many of the mentioned schemes that were part of the PMGKY, such as cash transfer for Jan Dhan account holders, widows' pensions, free supply of fuel (LPG), and income support for agriculture (see Table 5). In fact, 55\% of the women did not even have a Jandhan account to receive the cash transfer; $35 \%$ received the amount promised; but 10\% had not received it as of May 2020.

On widows' pensions, given that $91 \%$ of our sample consisted of widows, most were eligible for pensions from the state and central governments. However, as can be seen from Table 5, our study found that $60 \%$ of the participants were not listed as beneficiaries and so were excluded from the pension schemes. Of those who were listed as beneficiaries most did receive the benefits, but they constituted only $35 \%$ of the widows in our study. As for the Ujjwala scheme, $67 \%$ of the women were not listed as the beneficiaries. Of those listed as beneficiaries less than half received the fuel promised. 
Similarly, in the PM Kisan Sanman scheme, of the 684 women belonging to land owning households, $57 \%$ were not listed as beneficiaries. Although among those listed most did receive the Rs 2000 advance instalment, they constitute only a small percentage of those who needed the benefit.

The restrictions on mobility under lockdown also made it difficult for women to visit banks to check if money had been received or to withdraw cash. On an average, the banks were $15-20 \mathrm{kms}$ away and in some cases $40 \mathrm{kms}$ away. Among the women who did receive cash transfers, $33 \%$ said they could not withdraw the funds as they could not reach the banks due to the lockdown. Some others said they had to spend Rs 100-200 on private transport to reach the banks to withdraw the Rs 500 cash transfer or the widow pensions. In some of the villages, bank correspondents came to the villages to distribute the money, but women said that the agents charged a commission for doing so.

\section{Discussing the findings}

Our findings highlight how pre-existing inequalities linked to caste and singlehood aggravated the impact of COVID-19 pandemic for single women. These were further aggravated by the inadequate response by the state.

Widows and other single women are disadvantaged even in normal times in numerous ways: accessing agricultural schemes, institutional credit, agricultural inputs, and markets; in mobilising labour; and in getting a fair remunerative price for their produce. The pandemic induced lockdown further exposed these vulnerabilities. The already precarious lives of single women received a further jolt. During this crisis, support from public systems and social security schemes was warranted. However, the pre-existing exclusions, were further exacerbated, depriving many women of employment, pensions, rations and other social protections. The mounting debts and disruption in cash availability means that borrowings will increase in the coming months, pushing women deeper into debt and forcing some to sell their meagre assets. This will now delay the revival of their livelihoods.

An agrarian model dominated by cash crops like cotton and soyabean has also meant that households depend heavily on markets for food grains and pulses. The PDS failed to provide wheat and rice in the initial 2 weeks of the lockdown, while lack of cash, closure of markets, and transport bottlenecks meant that pulses, oils and other nutritionally essential food items were not available. The farming model based on monoculture, does not allow for a buffer stock of food grains to absorb shocks. Those households that did intercropping by growing pulses were able to bring at least some diversity into their diets. Cultivating Bt cotton requires heavy use of chemical fertilisers and weedicides which can also destroy vegetables, pulses or uncultivated food crops in the field. Several women said that they often negotiated with male members of the family for allocating parts of the farm to pulses and vegetables. However much of that diversity is now lost due to monocropping.

Some of the women discussed the need to move to chemical free, bio-diverse farming as a way forward, but they recognised that such a transition requires 
decisions to be taken by the entire village or the entire neighbourhood in order to prevent, birds and animals from attacking the few bio-diverse farms. Hence, despite recognising the problems of the cotton-soyabean cropping pattern, $94 \%$ said they would have to continue with the same farming model.

\section{Reflections and recommendations}

The pandemic has had a devastating impact on widows and other single women farmers. At the same time, it has presented us with an opportunity to correct the ways in which we conceptualise and design policies and programmes for ensuring livelihood security for women farmers. The findings presented here will also provide inputs to MAKAAM to help formulate its immediate and medium-term demands for rebuilding single women's livelihoods.

For full economic security, however, we need a comprehensive approach involving elements of both economic and social security. Economic security requires increasing women's access to productive resources (especially land), irrigation, credit, markets and remunerative prices. It also needs social protection, such as pensions, and (in the short term) direct cash transfers to tide women over immediate income shortfalls. Social security means access to affordable health care, adequate food and nutrition, housing and education. For effective delivery, such an approach would need the government to partner with communities through the intermediation of women's collectives, local NGOs and social networks, as has been demonstrated by several such collectives across India (Vikalp Sangam \& MAKAAM, 2021).

Agarwal's in-depth pre-COVID research on group farming by women in South India shows that women's collectives in Kerala have done significantly better than individual male farmers in terms of productivity and profits (Agarwal, 2018, 2020); and they have also fared much better during COVID-19 than individual small farmers (Agarwal, 2021a). Moreover, the research she and her colleagues have done on mixed-gender and women's collectives in Bihar and northern Bengal further reinforces the conclusion that women (and poor farmers more generally) are better protected economically in collectives than as individual farmers, both in normal times and in times of crises (Sugden et al., 2020). This, provides lessons and points to the need for women to work in groups as the way forward.

In addition, as Agarwal (2021a) argues, and as also highlighted in the submission made by MAKAAM to Niti Ayog in May $2020,{ }^{7}$ such an approach to livelihood security would need to have food and nutrition security at its core, with a farming model based on principles of agro-ecology and biodiversity rather than the currently active chemical-heavy model.

Despite these adversities, women with MAKAAM's support are fighting at the local level to make the public systems work. They have ensured that they receive

\footnotetext{
7 Niti Aayog is the National Institution for Transforming India. It was established in 2015 and is the premier policy 'Think Tank' of the Government of India, providing both directional and policy inputs. It replaced the earlier Planning Commission of India which had functioned from 1950 to 2015.
} 
their food entitlements and their pensions. They have also made efforts in making the MNREGA function by participating in the labour budget processes at the village level, getting job cards issued for women lacking such cards, and demanding that the number of guaranteed work days be raised under the MNREGA. Women cultivators are also sharing seed among themselves and supporting each other through exchange labour. The state of Maharashtra, however, continues to operate in a hierarchical manner, with no system in place to get feedback from communities on what they need, or forging alliances with communities for effective implementation. This is in contrast to Kerala where there is strong state and civil society partnership for eradicating poverty, and where the developmental approach rests on women-centric networks and group enterprises, especially group farming (see Agarwal, 2020, 2021a).

In the immediate future, our study indicates that the State needs to take several measures:

- Expand the food basket and universalise the Public Distribution System.

- Provide cash transfers to mitigate the debt crisis and compensate women farmers for wage loss for at least six months after March 2020.

- Support women farmers in new farming techniques for a more economically and ecologically sustainable farming model.

- Introduce mechanisms to expedite the issuance of job cards for single women for their inclusion in MNREGA and the EGS and ensure the effective implementation of the programme.

In the long run, however, the State would have to address the broader issues of structural reform such as inequities in access to resources, especially land. The pandemic has provided us an opportunity for rebuilding, supporting and strengthening ecologically sound rural livelihoods for women. However, this will need robust investments in agriculture as well as in water and other commons on which women depend.

Acknowledgements This article is based on numerous interactions with women farmers, with MAKAAM partners and a survey of single women done by SOPPECOM in association with MAKAAM. We thank all of them for their time and efforts as well as insights. We also thank Bina Agarwal for encouraging us to write this paper and for her substantial comments on earlier drafts for bringing it to its final publication.

\section{References}

Agarwal, B. (2018). Can group farms outperform individual family farms? World Development, 108, 57-73.

Agarwal, B. (2020). Does group farming empower rural women: Lessons from India's experiments. Journal of Peasant Studies, 47(40), 841-872.

Agarwal, B. (2021a). Livelihoods in COVID times: Gendered perils and new pathways in India. World Development, 139, 105312.

Agarwal, B. (2021b). Reflections on the less visible and less measured: Gender and Covid-19 in India. Gender and Society, 35(2), 244-255. 
Agarwal, B., Anthwal, P., \& Mahesh, M. (2021). How many and which women own Land in India? Intergender and intra-gender gaps. Journal of Development Studies. https://doi.org/10.1080/00220388. 2021.1887478

Bera, S. (2020). Stories of distress from small borrowers. Mint. https://www.livemint.com/news/india/ stories-of-distress-from-small-borrowers-11597585864192.html. Accessed 20 Feb 2021.

Central Statistical Organization CSO. (2020). COVID-19 induced Lockdown-How is the Hinterland Coping? https://ruralindiaonline.org/library/resource/covid-19-induced-lockdown-how-is-the-hinte rland-coping/. Accessed 15 June 2021.

Centre for Sustainable Employment (CSE). (2020) COVID-19 Livelihood Survey. https://cse.azimpremji university.edu.in/wp-content/uploads/2020/06/Compilation-of-findings-APU-COVID-19-Livel ihoods-Survey_Final.pdf. Accessed 25 July 2021.

Chishti, S. (2020). New Research: How lockdown has impacted India's farmers, their yields. Indian Express. https://indianexpress.com/article/explained/how-coronavirus-lockdown-has-impactedindian-farmers-their-yields-6421569/. Accessed 20 Feb 2021.

Centre for Labour Research and Action (CLRA), et al. (2020). Rapid Assessment of Unorganised, Informal and Migrant Workers. http://clra.in/files/documents/6687c0d7-6bdd-4c8c-a6ab-98c79ef70d11. pdf. Accessed 22 Mar 2021.

Communist Party of India (Marxist)-Centre of Indian Trade Unions (CPI(M)-CITU). (2020). Survey of Migrant Workers in Distress in Delhi under COVID-19 Lockdown. https://www.docdroid.net/uJ1YF IJ/cpim-citu-survey-of-migrant-workers-in-delhi-24-april-2020-pdf. Accessed 15 June 2021.

Dasgupta, J., \& Sona, M. (2020). A gender-responsive policy and fiscal response to the pandemic. Economic and Political Weekly, 55(22), 13-17.

Deshpande, A. (2020). The Covid-19 pandemic and lockdown: First order effects on Gender Gaps in Employment and Domestic Time Use in India. GLO Discussion Paper No. 607. Global Labour Organization, Essen. http://hdl.handle.net/10419/222416. Accessed 25 July 2021.

Government of India (GOI). (2020). Finance Minister announces Rs 1.70 Lakh Crore relief package under Pradhan Mantri Garib Kalyan Yojana for the poor to help them fight the battle against Corona Virus. Ministry of Finance. https://pib.gov.in/PressReleaseIframePage.aspx?PRID=16083 45. Accessed 25 Mar 2021

Directorate of Economics and Statistics, Government of Maharashtra (GoM). (2019-20). Economic Survey of Maharashtra, 2019-20. https://mahades.maharashtra.gov.in/files/publication/ESM_2019_20_ Eng_Book.pdf. Accessed 25 Mar 2021.

Kulkarni, S. (2020). Locked in a crisis: Concerns of rural women. Economic and Political Weekly, $55(23), 15-18$.

Mahila Kisan Adhikar Manch (MAKAAM). (2018). Key Concerns of Women Farmers from Suicide affected households of Maharashtra. https://www.soppecom.org/pdf/summary-brochure-english. pdf. Accessed 22 Mar 2021.

Mahila Kisan Adhikar Manch (MAKAAM). (2020). Unlocking the Crisis: Understanding impacts of COVID-19 and subsequent lockdown on single women farmers of Maharashtra. https://www.soppe com.org/pdf/Unlocking\%20the\%20crisis-english-final\%20report210620.pdf. Accessed 22 Mar 2021.

MNREGA (2005). https://nrega.nic.in. Accessed 25 July 2021.

Mudur, G.S. (2020). Survey suggests worker hunger under lockdown. The Telegraph. Retrieved from https://www.telegraphindia.com/india/survey-suggests-worker-hunger-under-lockdown/cid/17679 17. Accessed 25 Mar 2021.

National Crime Records Bureau (NCRB). (2018). Accidental Deaths and Suicides in India. https://ncrb. gov.in/en/accidental-deaths-suicides-india-2018. Accessed 25 Mar 2021.

NFSA (2013). https://nfsa.gov.in/portal/NFSA-Act. Accessed 25 July 2021.

Raina, V., \& Ananya, C. (2021). The Lockdown in India: Understanding the Matrix of Caste, Class and Gender. Economic and Political Weekly, 56(8), 12-16.

SEWA Bharat. (2020). Gendered precarity in the lockdown: What the lockdown shows us about the precarity of women workers. https://www.wiego.org/sites/default/files/publications/file/Gendered_ Precarity_SB_Lockdown.pdf. Accessed 25 Mar 2021.

Shah, A., \& Mehta, A. (2010). Experience of the Maharashtra Employment Guarantee Scheme: are there lessons for NREGS? Working Papers ID. 2774. E Social Sciences. https://ideas.repec.org/p/ess/wpaper/id2774.html. Accessed 25 Mar 2021. 
Stranded Workers Action Network (SWAN). (2020). 32 Days and Counting: COVID-19 Lockdown, Migrant Workers, and the Inadequacy of Welfare Measures in India. https://ruralindiaonline.org/ library/resource/21-days-and-counting-covid-19-lockdown-migrant-workers-and-the-inadequacyof-welfare-measures-in-india/. Accessed 22 Mar 2021.

Sugden, F., Agarwal, B., Leder, S., Saikia, P., Raut, M., Kumar, A., \& Ray, D. (2020). Experiments in farmers' collectives in Eastern India and Nepal: Process, benefits, and challenges. Journal of Agrarian Change. https://doi.org/10.1111/joac.12369

Vikalp Sangam and Mahila Kisan Adhikar Manch (MAKAAM). (2021). Seeding Hope: Women's Collectives Create Pathways for Change. https://vikalpsangam.org/article/seeding-hope-womens-colle ctives-create-pathways-for-change/. Accessed 25 Mar 2021.

Publisher's Note Springer Nature remains neutral with regard to jurisdictional claims in published maps and institutional affiliations.

\title{
Authors and Affiliations
}

\author{
Seema Kulkarni ${ }^{1,2}$ (D) Sneha Bhat ${ }^{1,2} \cdot$ Pallavi Harshe ${ }^{1,2} \cdot$ Swati Satpute $^{1,2}$ \\ Sneha Bhat \\ bhatsneha@gmail.com \\ Pallavi Harshe \\ pallavi.harshe@gmail.com \\ Swati Satpute \\ swatisatpute236@gmail.com \\ 1 SOPPECOM, Pune, India \\ 2 MAKAAM, Secunderabad, India
}

